\title{
COVID-19 and Low Uric Acid Levels
}

\section{COVID-19 ve Düşük Ürik Asit Seviyeleri}

\author{
Mesut Aydın $\oplus^{\oplus}$, Alev Gül $\oplus^{\oplus}$, Yaren Dirik $\oplus^{\oplus}$, Ahmet Cumhur Dülger ${ }^{\circledR}$, \\ Harun Egemen Tolunay $₫$
}

Editöre Mektup Letter to Editor

Received/Geliş: 03.07.2020 Accepted/Kabul: 01.10.2020 First Online: 28.09 .2021

Mesut Aydın Van Yüzüncü Yıl Üniversitesi Tıp Fakültesi, Gastroenteroloji Bilim Dalı, Van - Türkiye gmstaydin@gmail.com ORCID: 0000-0002-7411-1067

Y. Dirik 0000-0003-4582-8672 Van Yüzüncü Yıl Üniversitesi Tıp Fakültesi, Gastroenteroloji Bilim Dal, Van, Türkiye

A. Gül 0000-0002-5768-7814 A.C. Dülger 0000-0002-9328-5185 Giresun Üniversitesi Tıp Fakültesi, Gastroenteroloji Bilim Dalı, Giresun, Türkiye

H.E. Tolunay 0000-0002-8922-4400 Etlik Zübeyde Hanım Kadın Hastalıkları Eğitim Hastanesi, Perinatoloji Kliniği, Ankara, Türkiye

Cite as: Aydin $M$, Gül $A$, Dirik $Y$, Dülger $A C$ Tolunay HE. COVID-19 and low uric acid levels. Tepecik Eğit. ve Araşt. Hast. Dergisi. 2021;31(3):436-8.
Dear Editor

Low serum uric acid predicts severely ill patients, the earliest laboratory indicator of sepsis ${ }^{(1)}$.

Novel coronovirus (COVID-19) infection is the one of the most fearful pandemics in recent decades and is associated with increased rates of mortality with well known risk factors including diabetes mellitus, ischemic hearth disease and cancer ${ }^{(2)}$.

The relationship between serum uric acid (SUA) and prognosis in COVID-19 patients is unclear. Our aim was investigate whether baseline and ongoing serum uric acid (SUA) levels was an independent predictor of disease severity in patients who were treated for COVID-19 infection. Favipravir, a novel pseudo-purine analog, is potent and effective for treating COViD-19 infection ${ }^{(3)}$.

Thus; we also aimed to evaluate the effect of oral favipravir on SUA levels.

We describe a MD patient with Covid-19 whom had prior nephrectomy. Severe acute respiratory syndrome in coronavirus 2 (SARSCoV-2) infection was confirmed by computed tomography of toraks, reverse-transcriptase-polymerase-chainreaction (RT-PCR) with assay.

Further diagnostic work-up also revealed lymphopenia, higher CRP levels, and elevated levels of D-dimer. Urinalysis did not reveal hemoproteinuria and cellular casts. Urine protein/creatinine was also in normal ranges. Renal ultrasound showed unilateral nephrectomy with normal seized remnant kidney. In the absence of another etiology, we concluded he had pneumonia possibly associated with COVID-19 infection, and started on hydroxychloroquine (HCQ) 400 mg per day and azitromycin 500 mg once a day. Due to higher D Dimer levels, low molecular weight heparin 4000 unit per day subcutaneously was also added to his treatment regimen. Five days later he developed dyspnea, shortness of breath, repetative cough, with fever. In this setting, his CRP level rose to $50 \mathrm{U} / \mathrm{L}$ from a baseline of $16 \mathrm{U} / \mathrm{IL}$, and laboratory tests later showed lactic ascidosis consistent with SIRS. Thus, HCQ has been

(C) Telif hakkı T.C. Sağıık Bakanlığı İzmir Tepecik Eğit. ve Araşt. Hastanesi. Logos Tıp Yayıncılık tarafindan yayınlanmaktadı. Bu dergide yayınlanan bütün makaleler Creative Commons Attf-GayriTicari 4.0 Uluslararası Lisansı ile lisanslanmıștır.

(c) Copyright Association of Publication of the T.C. Ministry of Health Izmir Tepecik Education and Research Hospital.

This journal published by Logos Medical Publishing.

Licenced by Creative Commons Attribution-NonCommercial 4.0 International (CC BY) 
Table 1.

\begin{tabular}{|c|c|c|c|}
\hline & Case 1 & Case 2 & Case 3 \\
\hline $\begin{array}{l}\text { White-cell count (per mm3) } \\
\text { Total leukocyte count }\end{array}$ & 8060 & 5790 & 31900 \\
\hline \multicolumn{4}{|l|}{ Differential count (per mm3) } \\
\hline Total neutrophils & 4440 & 4390 & 26800 \\
\hline Total lymphocytes & 1410 & 840 & 2900 \\
\hline Total monocytes & 2100 & 490 & 2000 \\
\hline Platelet count (per mm3) & 213000 & 201000 & 22200 \\
\hline Hemoglobin (g/liter) & 12,7 & 12,3 & 11,5 \\
\hline Albumin (g/liter) & 41,9 & 42,5 & 31,7 \\
\hline Alanine aminotransferase (U/liter) & 80 & 22 & 25 \\
\hline Aspartate aminotransferase (U/liter) & 51 & 20 & 59 \\
\hline Lactate dehydrogenase (U/liter) & 262 & 164 & 209 \\
\hline Creatinine (mg/dl) & 1,18 & 0,75 & 0,82 \\
\hline Creatine kinase (U/liter) & 572 & 99 & 186 \\
\hline High-sensitivity cardiac troponin I ( $\mu \mathrm{g} / \mathrm{L})$ & 0,006 & 0,005 & 0,014 \\
\hline Prothrombin time (sec) & 10,6 & 10,4 & 13 \\
\hline Activated partial-thromboplastin time (sec) & 27,5 & 24 & 30,0 \\
\hline Fibrinogen (mg/dL) & 506.0 & 282,7 & 717,73 \\
\hline D-dimer (ng/ml) & 552 & 153 & 1691 \\
\hline Serum ferritin ( $\mu \mathrm{g} /$ liter) & 1096,00 & 80,68 & 555,50 \\
\hline Procalcitonin (ng/ml) & 0,08 & 0,05 & 1,40 \\
\hline C-reactiveprotein (mg/liter) & 84,27 & 3,24 & 238,64 \\
\hline Uric acid $(\mathrm{mg} / \mathrm{dl})$ day one & 5,23 & 4,18 & 4,30 \\
\hline
\end{tabular}

continued for 5 days. At the sixth day of ongoig treatment, patient was ultimately treated with favipravir and Tazobactam, which resulted in improvement in clinical symptoms. Laboratory parameters including SUA, CRP, lipid parameters became normal and lymphopenia resolved at the end of sevnth day of favipravir treatment. Trajectories of SUA levels of the patients were depicted in Table 1.

Further laboratory details are summarized in Table 2. He had no medical histrory of pulmonary diseases, hypertension, diabetes mellitus, malignancy and atrial fibrillation. Since the SUA level is affected by the renal dysfunction, we selected that cases who had without chronic kidney disease (CKD) for searching the association between the SUA level and the disease progression. Two other patients with similar findings were seen at the specialized hospital unit for patients with Covid-19 at our hospital.

Serum uric acid, hematologic parameters ,simple biochemical tests, $D$ dimer levels, serum ferritin and C-reactive protein (CRP) were also measured at baseline and at the end of favipravir treatment. All of our patients switched to favipravir from HCQ treatment due to lack of clinical and radiologic response. At the end of additional seventh days of the favipravir treatment all patients's SUA levels were normali- 
Table 2.

Case 1

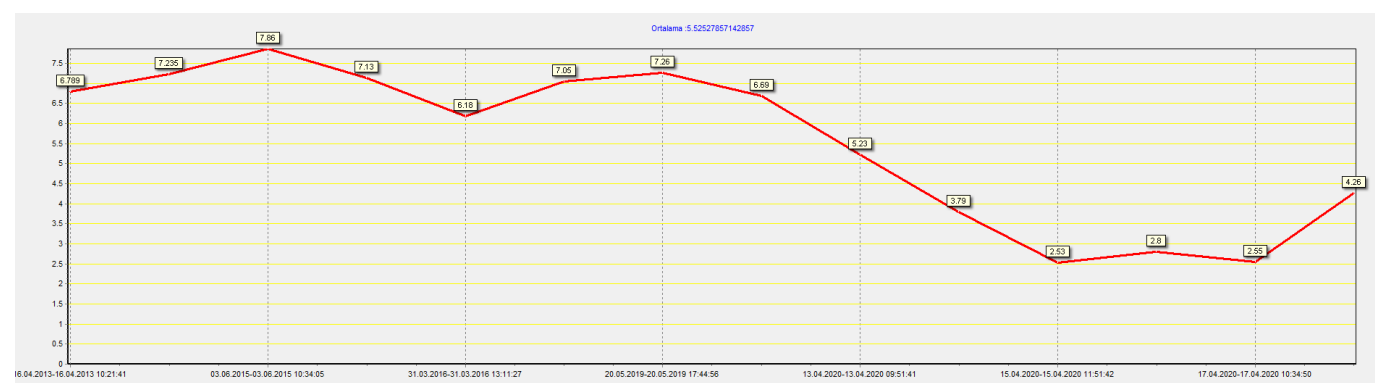

Case 2

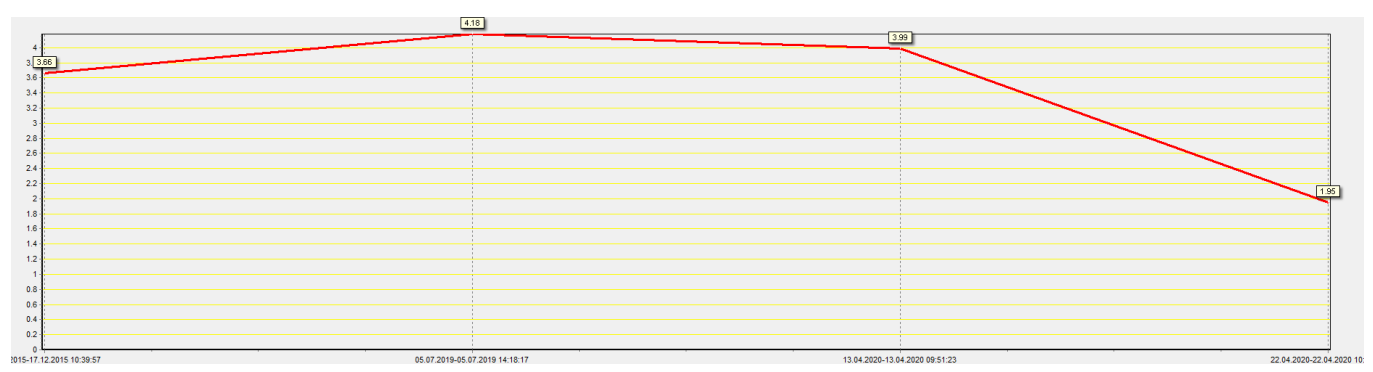

Case 3

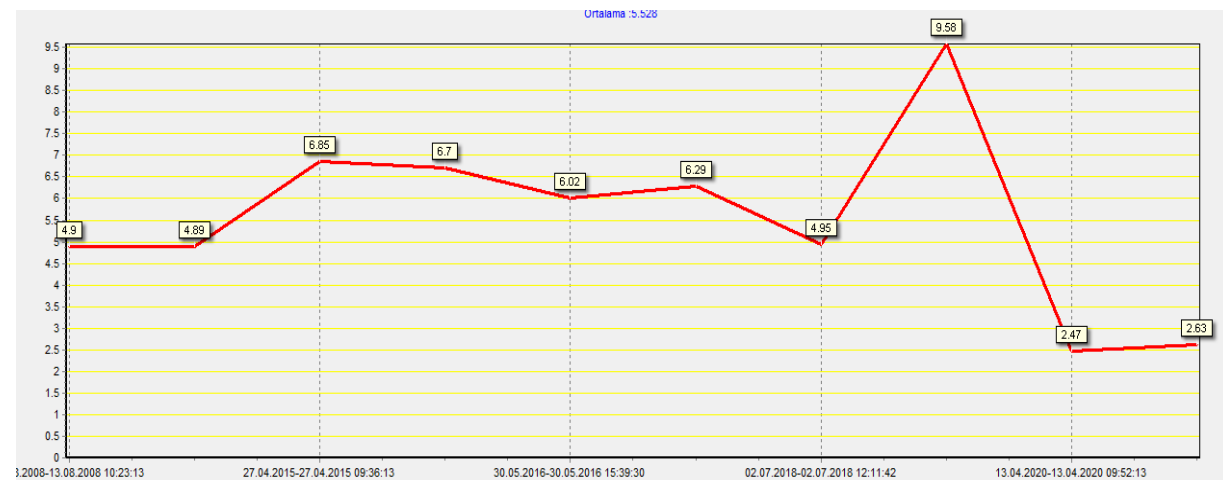

zed in line with their rapid clinical and radiologic improvements.

In conclusion, HCQ administration significantly reduced the serum uric acid levels in patients with COViD-19 infection when compared with baseline SUA levels. No significant difference in the changes in serum creatinin and sodium, was identified in the presented cases. Intensive SUA lowering with COVID19 infection was also correlated with disease severity. Rapid clinical detoriation was also observed among those patients with hypouricemia without any effect to renal functions. A larger study is underway to determine which patient groups might affect most from COVID-19 infection during favipravir treatment.

\section{REFERENCES}

1. Giovannini I, Chiarla C, Giuliante F, Vellone M, Ardito F, Pallavicini F, Nuzzo G. Biochemical and clinical correlates of hypouricemia in surgical and critically ill patients.Clin Chem Lab Med. 2007;45(9):1207-10. [CrossRef]

2. Taisheng L. Diagnosis and clinical management of severe acute respiratory syndrome Coronavirus 2 (SARS-CoV-2) infection: an operational recommendation of Peking Union Medical College Hospital (V2.0), Emerging Microbes \& Infections. 2020;9(1):582-5. [CrossRef]

3. Du YX, Chen XP. Favipiravir: Pharmacokinetics and Concerns About Clinical Trials for 2019-nCoV Infection. Clin Pharmacol Ther. 2020 Apr 4. [CrossRef] 